necessity, and so on. Although all these areas are compatible with a research interest, that interest should arise out of a personal commitment and involvement with the subject. Unwilling researchers are unlikely to produce good results. It is therefore improbable that they will enhance the reputation of psychiatry as a serious scientific subject.

Moreover, the current situation is often difficult for those trainees who desire to obtain research experience. Registrars are rarely given the support and advice necessary to obtain a higher research degree as a result of their work. In many jobs no encouragement is given to find time for research. Finally, trainees are frequently advised to aim for the maximum number of publications for the purposes of enhancing the curriculum vitae. Although the brevity of an "e = mc2" may elude psychiatry for some time, qualities of conciseness, precision and economy of words are virtues which should not be ignored. The uncertainties of our subject should not be further amplified by superfluous publication.

St Lawrences Hospital

Simon Halstead

Caterham, Surrey CR3 5 YA

\section{Madness in opera}

\section{DeAr Sirs}

I read with some interest Dr Jones' article on the Psychiatry of Opera (Psychiatric Bulletin, May 1990, 14, 306-307). I was rather surprised to see that he failed to mention the representation of madness in opera. I would suggest that the study of how different composers depicted madness in opera reflect on the current attitudes of the day.

Mental illness as represented by opera can be divided into three basic periods: the first is 'The Mad Scene', followed by the shunning of mental illness in opera. The third period is the rise of the psychoanalytical opera.

The Mad Scene-The first classical 'Mad Scene' appears in Handel's (1685-1759) 'Orlando' (1733). King Orlando goes mad in Arcadia for the love of a shepherdess. He returns to the sane world when she returns his love. DSM-III-R would probably classify this as a brief reactive psychosis. This type of madness was acceptable when removed to a distant/ pastoral setting. This type of illness tended to be confided to regal sufferers. The great master of 'The Mad Scene' during early 19th century opera was unequivocally Gaetano Donizetti (1797-1848). The best example of his considerable output is Lucia di Lammermoor (1835). Lucia, in a state of madness on her wedding night, murders her new husband. After a stunning coloratura aria, still in her blood-stained wedding dress, she dies. Her free spirit is represented by an obligato flute. The point of this is clear: through madness Lucia discovers freedom, not merely from her unwanted husband but from life itself. Thus madness relates to heaven, freedom and liberty. Of course, at this time the great humanitarian movement in psychiatry was gaining momentum. In England the first patients to be removed from physical restraint were in York in 1796.

The rise of physical illness - During the middle of the 19th century, opera composers steered away from madness. They preferred to use physical illness as a symbol of purity. TB was used as a common method of escape to death, e.g. La Traviata (1853). Was this because insanity was too real and close to home for many of these composers? Wagner never really dealt with mental illness in any of his works. I suspect this was because it offended his Germanic view of purity. His patron, Ludwig II of Bavaria, was clearly psychotic and probably committed suicide in 1886 . Verdi (1813-1901) made a few poor attempts of portraying mental illness on the opera stage. This was mainly evident in his early works, e.g. Nabucco (1843). These attempts were dramatic devices, poorly represented musically. He clearly found madness a difficult subject to write about, finding it was a little too close to home. He was never able to start his great project of an opera based on King Lear; he found the subject too stressful.

The Psychoanalytical Opera-During the latter part of the 19th and early 20th century one starts to see a change in the psychological treatments in opera; Greek legends as a metaphor for the emotional human condition were often used. This parallels the rise of the European psychoanalytical schools. The best example of this is Richard Strauss's (1864-1949) Elektra (1909). He deals with them in a tense and strongly sexual way. This idea was taken up by Stravinsky (1888-1980) in Oedipus Rex (1929). In 1925 Alban Berg (1885-1935) finished Wozzeck, an opera influenced by the horror of the first world war. This opera presents madness in a very different light, Wozzeck's insanity is not a release to a better world but a descent to hell. In effect we have witnessed a change in the representation of madness. Initially madness equalled beauty and freedom, it then metamorphosed into a living hell.

I am hopeful that this area of interest will awaken further study and thought.

\section{Gordon Hospital \\ London SWIV 2RH}

DEAR SIRS

Dr Brener in responding to my introductory article on the psychiatry of opera (Psychiatric Bulletin, May $1990,14,306-307)$ seems to have missed the point that my article was an introduction to a series of articles which he has partly pre-empted. I would agree, at a general level, with his representation of 